\title{
Atlantic Studies
}

\section{Absences and Opacities: Reading "Hidden" Stories of Seafaring in B. Traven's Ship of the Dead and Francisco Goldman's The Ordinary Seaman \\ --Manuscript Draft--}

\begin{tabular}{|c|c|}
\hline Author Comments: & \\
\hline Manuscript Number: & RJAS-2017-0025R1 \\
\hline Full Title: & $\begin{array}{l}\text { Absences and Opacities: Reading "Hidden" Stories of Seafaring in B. Traven's Ship of } \\
\text { the Dead and Francisco Goldman's The Ordinary Seaman }\end{array}$ \\
\hline Article Type: & Original Article \\
\hline Corresponding Author's Institution: & \\
\hline First Author: & Cornelia Graebner \\
\hline Order of Authors: & Cornelia Graebner \\
\hline Manuscript Region of Origin: & UNITED KINGDOM \\
\hline Abstract: & $\begin{array}{l}\text { This article engages the historical approach to the "Hidden Atlantic" (Michael Zeuske) } \\
\text { in a complementary, literature-based analysis. It argues that the diverse facets of the } \\
\text { "hidden" require diverse methodological approaches; firstly, because the "hidden" has } \\
\text { several dimensions, and secondly, because the ethical impetus of the cultural analyst } \\
\text { or the historian requires a choosing of sides. Authors of works labelled as "literary" or } \\
\text { "fiction," which are nevertheless known to have a close relationship to real-life } \\
\text { experience, negotiate this fine line. The article analyses in greater detail two such } \\
\text { works - B. Traven's Das Totenschiff (1926) and Francisco Goldman's The Ordinary } \\
\text { Seaman (1997) - with reference to their treatment of the "Totenschiff" and its crews in } \\
\text { the context of predatory capitalism. } \\
\text { In the first instance, the article explores two dimensions of the "hidden": the "forcibly } \\
\text { rendered absent" (Boaventura de Sousa Santos) and the "opaque" (Édouard Glissant). } \\
\text { The literary figure of the "Totenschiff," the "ship of the dead," is deployed by the } \\
\text { authors to bring to the attention of the readers the plight of the crewmembers who have } \\
\text { been expulsed (Saskia Sassen) from society, the callousness and impunity of the } \\
\text { perpetuators and agents of predatory capitalism who exploit them, and the complicity } \\
\text { of the "civilized" populations who acquiesce to this expulsion. While they do this, the } \\
\text { authors use "literariness" to preserve the opacity that protects the expulsed. Through a } \\
\text { comparative analysis of the interplay of absences and opacities in both novels, with a } \\
\text { particular focus on deviant and hegemonic masculinities, this article explores } \\
\text { possibilities for cultural analysts to engage with the "hidden," without jeopardizing the } \\
\text { relative safety granted to the expulsed by opacity. }\end{array}$ \\
\hline Additional Information: & \\
\hline Question & Response \\
\hline $\begin{array}{l}\text { Number of Words (Minimum approx. } \\
\text { 8,000; Maximum approx. 10,000) }\end{array}$ & 11820 \\
\hline $\begin{array}{l}\text { Is this paper to be entered in the Atlantic } \\
\text { Studies Early Career Essay Prize? To be } \\
\text { eligible for this you must be presently } \\
\text { enrolled in a Ph.D. program or within } \\
\text { three years of having received your Ph.D. } \\
\text { Choosing to have your paper considered } \\
\text { for the prize will not affect your eligibility } \\
\text { for publication in the journal. }\end{array}$ & No \\
\hline Response to Reviewers: & \\
\hline
\end{tabular}




\title{
Absences and Opacities: Reading “Hidden" Stories of Seafaring in B. Traven's Ship of the Dead and Francisco Goldman's The Ordinary Seaman
}

\begin{abstract}
This article engages the historical approach to the "Hidden Atlantic" (Michael Zeuske) in a complementary, literature-based analysis. It argues that the diverse facets of the "hidden" require diverse methodological approaches; firstly, because the "hidden" has several dimensions, and secondly, because the ethical impetus of the cultural analyst or the historian requires a choosing of sides. Authors of works labelled as "literary" or "fiction," which are nevertheless known to have a close relationship to real-life experience, negotiate this fine line. The article analyses in greater detail two such works B. Traven's Das Totenschiff (1926) and Francisco Goldman's The Ordinary Seaman (1997) - with reference to their treatment of the "Totenschiff" and its crews in the context of predatory capitalism.

In the first instance, the article explores two dimensions of the "hidden": the "forcibly rendered absent" (Boaventura de Sousa Santos) and the "opaque" (Édouard Glissant). The literary figure of the "Totenschiff," the "ship of the dead," is deployed by the authors to bring to the attention of the readers the plight of the crewmembers who have been expulsed (Saskia Sassen) from society, the callousness and impunity of the perpetuators and agents of predatory capitalism who exploit them, and the complicity of the "civilized" populations who acquiesce to this expulsion. While they do this, the authors use "literariness" to preserve the opacity that protects the expulsed. Through a comparative analysis of the interplay of absences and opacities in both novels, with a particular focus on deviant and hegemonic masculinities, this article explores possibilities for cultural analysts to engage with the "hidden," without jeopardizing the relative safety granted to the expulsed by opacity.
\end{abstract}

Keywords: Hidden Atlantic; ship of the dead; expulsed; opacity; sociology of absences; predatory capitalism; B. Traven; Francisco Goldman 

Das feste Land ist mit einer unübersteigbaren Mauer umgeben, ein Zuchthaus für die, die drinnen sind, ein Totenschiff oder eine Fremdenlegion für die, die draussen sind. Es ist die einzige Freiheit, die ein Staat, der sich zum Extrem seines Sinnes entwickeln will und muss, dem einzelnen Menschen, der nicht numeriert werden kann, zu bieten vermag, wenn er ihn nicht mit kühler Geste ermorden will.

Firm land is surrounded by an insurmountable wall; there's prison for those who are inside, and a "Totenschiff" or a foreign legion for those outside. This is the only freedom that a State which desires to, and must, evolve to the limits of its own reason is able to offer those human beings who, each and every one, cannot be numbered - that is, if the State does not wish to assassinate them with a coolish gesture.

(B. Traven, Das Totenschiff) ${ }^{1}$

"Ships of the dead," or "death ships," or "Totenschiffe" are extreme manifestations of tramp ships, "which plied from port to port in search of odd cargoes"2 when the age of sail came to its end in the late $19^{\text {th }}$ and early $20^{\text {th }}$ century. The "Totenschiff"3 masquerades as a ship that operates within the legal framework of maritime law; but it is in fact a space where those who Saskia Sasssen calls "the expulsed" are warehoused and exploited: those who have no land (therefore cannot be assigned to a place), no passports (therefore cannot be legally deported), no money (therefore cannot buy their way out of anything), and no social standing (therefore have no-one who vouches for them or enquires after them $)^{4}$. Gulddall has argued that the Totenschiff is another manifestation of the camp as theorized by Agamben ${ }^{5}$; but I would like to look at it here from a different angle: as a figure of what Michael Zeuske has termed the "Hidden Atlantic,"6 a term I understand as one that can be expanded to include all seas and oceans. However, unlike Zeuske's case studies, the Totenschiff crews do not inhabit a past historical moment but an impasse: a stretch of time that has no measure and no end, seeing as the 
crewmembers are already "dead," and their temporality can therefore not be normally transferred into narrative genres. ${ }^{7}$ The "Totenschiff” is a feature of predatory capitalism in any of its historical moments, and the impasse comes to encompass the relevant elements and characteristics of all these moments and arranges them in ongoing formations of this systemic entity. Because this impasse occupies the present as well as the past, dragging the crew out of the opacity of the hidden and into the limelight of critical attention would hand them over to their enemies, whether those are profiteers and their willing executioners, or agents of the State. How, then, can we as scholars and critical thinkers expose and denounce the systemic conditions, and the systemically integrated actions, without sacrificing the crews' safety? Therefore, here I look at novels by two authors who have answered this question by smuggling these ships and their crews into quasi-fictional discourses such as "novels": B. Traven's Das Totenschiff (1926) and Francisco Goldman's The Ordinary Seaman (1997). Kept safe in the borderlands between fact and fiction where the unsayable and unacceptable can be explored, the authors convey to us the plight of the "Totenschiff" crews without dragging the sailors out of protective opacity. Published seventy years apart, at opposite ends of the $20^{\text {th }}$ century, these novels tell us much about capitalist arrangements whereby expulsed populations are made to depend on those who exploit them, and with which state authorities and "civilized society" are complicit.

Traven introduces us to the "Totenschiff" Yorikke and the "Leichenschiff” Empress of Madagascar $^{8}$ and their crews of wretched, mostly European sailors. Das Totenschiff is the first novel of this notoriously enigmatic author, who first appeared under this surname in 1926 in the Mexican port of Tamaulipas. ${ }^{9}$ Until his death in Mexico City in 1969, he wrote novels - now by many considered classics - about the plight of the most oppressed populations of Mexico; only Das Totenschiff is set in post-WWI Europe. The story is told by a US-American sailor known first as Gale, and then as Pippip. He loses his seaman's card, and because he has no other papers, relatives, a fixed address or connections, the US-American consulates refuse to accept that he is indeed US-American and effectively expulse him from the possibility of legal employment. In search of a ship that will take him 
on anyway, he embarks on an odyssey on foot through Western Europe, and is arrested and deported from one country to another several times. He finally accepts work as a coal-drag on the "Totenschiff" Yorikke. The coal-drag is the lowest-ranked member of the stokehold crew, or "black gang." His work is the least respected, worst paid, physically harshest, and most dangerous occupation on any ship, and even more so on the "Totenschiff." ${ }^{10}$ From then on, Pippip gets to partake in an experience that is normally foreclosed to white US-American men; as his fellow coal-drag Stanislav Koslovski explains, a "yank's" nationality normally protects him from working on a "Totenschiff." ${ }^{11}$ Stanislav, himself made stateless by bureaucratic deadlines that do not take into consideration the non-linear temporalities of border-crossing seafarers, becomes Pippip's friend and mentor. He acts as the memory of the Yorikke, guarding and sharing the stories of those who worked and died on her. The book consists of three parts: the first tells of Gale's journey through Europe on foot, the second is set on the Yorikke, and the third is set on the Empress of Madagascar, onto which Pippip and Stanislav are abducted, or shanghaied. When the Empress sinks, only Pippip and Stanislav survive. They tie themselves to a plank and float in the ocean. After several hours, Stanislav starts to fantasize about the seeming safety of Yorikke, cuts his rope and, despite Pippip's pleading, gives himself up to the ocean. Pippip survives, but we only know this because he tells us the story from an eternally present moment indicated by the evocation of a conversational situation that is explicated by the recurrent direct address of an anonymous male listener, to whom he seems to be telling his story for money. ${ }^{12}$

Goldman, a journalist and the author of three novels and two non-fiction books, is known for his explorations of the borderline between testimony, storytelling, journalism and fiction, as well as for taking one of these genres as a starting point and then contaminating it with elements of all the others. ${ }^{13}$ The Ordinary Seaman is his second novel. It was inspired by a newspaper story on an abandoned ship, Goldman's encounter with some of the crewmembers, and the report that one of them wrote on his experience. The crew, all from Central America, were hired under the pretence of repairing a ship to then sail with it. They were subsequently abandoned on this ship, which was docked at a derelict quay 
in Brooklyn. Seaman fictionalizes this story. The novel's protagonists are a crew of mostly very young men from Nicaragua and Honduras, left destitute by war and neocolonialism. Key characters among them are Esteban, who fought in a voluntary battalion of the Sandinista army against the U.S. sponsored Contra and is emotionally deeply scarred by the death-in-combat of his lover Marta, and the elderly Bernardo, who is hired as officers' waiter and is among the very few characters who have previously gone to sea. Other important characters include the "captain" Elías and the "first mate" Mark, who are also the owners of the ship, though they never admit to this, and a Ship Visitor. The latter works for a non-governmental seafarers' organization, is alerted to the ship by a passer-by, and wishes to rescue the crew from their abandonment. Like Totenschiff, Seaman is set in the present of the impasse, created here through internal monologue rather than conversation. The narration is focalized mostly through Esteban, occasionally through Bernardo, and over significant stretches through the Ship Visitor, Elías, or Mark. The plot forks about half-way through the novel, due to different actions undertaken by Bernardo and Esteban: Bernardo resorts to outside help, which arrives in the form of the Ship Visitor; Esteban claims his "right to escape" and finds a community of solidarity for himself and those shipmates who choose the life of the undocumented immigrant over return to Central America.

Over the following pages, I will engage in a close analysis of two elements of both novels which relate the systemic entity of the "Totenschiff" to two aspects of the methodologies of disciplines of the cultural and historical domains: of what is actively rendered absent, and of what needs to remain in protective opacity.

\section{Actively rendered absent: The "Totenschiff" and its crew}

The English translation of the novel's German title is indicative of the first "absence" I would like to address here. The Death Ship focuses on the concept of "death"; the Totenschiff focuses on the people, the dead. The abstraction implicit in the focus on death actively renders absent the knowledge and experience of the crews, which is rooted in embodiment. To appreciate the implications of this, it is 
useful to consider Boaventura de Sousa Santos' analysis of what is "actively produced as nonexistent." ${ }^{14}$ Santos argues that

There is no single, univocal way of not existing. The logics and processes through which hegemonic criteria of rationality and efficiency produce the non-existence of what does not fit them are various. Non-existence is produced whenever a certain entity is disqualified and rendered invisible, unintelligible or irreversibly discardable. What unites the different logics of production of non-existence is that they are all manifestations of the same rational monoculture. $^{15}$

These five logics of dominant epistemology are the monoculture or rigour of knowledge, linear time, social classification, scale, and productivity. As we will see, the "Totenschiff" and its populations do not fit into any of them.

In terms of social classification, the early $20^{\text {th }}$ century crew in Totenschiff are the descendants of the survivors of internal dispossession and repression in Europe, and of colonial dispossession and repression almost everywhere else. They are the early $20^{\text {th }}$ century manifestation of "all those outside of organized wage labor, as well as those whose activities comprised the culture, tradition, and autonomous self-understanding of this volatile, questioning, and unsteady proletariat"16; they are the "motley crowd" (Marx) which turned into those who Linebaugh and Rediker describe as the "motley crew" of $17^{\text {th }}$-century ocean liners, and who also man $20^{\text {th }}$-century "Totenschiffe": “ (. . .) motley could also refer to a colourful assemblage, such as a crowd of people whose tatterdemalion dress made it interesting. A motley crowd might very likely be one in rags, or a "lumpen"'-proletariat (from the German word for "rags")." 17 The late $20^{\text {th }}$ century crew in Seaman are recruited from amongst the survivors of colonialism, imperialism, and racism; those who Nelson Maldonado-Torres, with reference to Frantz Fanon, designates as the damnés: 
The damné (condemned) is a subject who exists in a permanent "hell," and as such, this figure serves as the main referent or liminal other that guarantees the continued affirmation of modernity as a paradigm of war. The hell of the condemned is not defined by the alienation of colonized productive forces, but rather signals the dispensability of racialized subjects, that is, the idea that the world would be fundamentally better without them. ${ }^{18}$

Moreover, the damné is rendered absent by the Western conception of being because the damné "has non-ontological resistance in the eyes of the dominant group. [...] The damné exists in the mode of notbeing there, which hints at the nearness of death, at the company of death." 19

Totenschiff implies in and of itself a reflection on the relationship between knowledge and experience, and on the ways in which certain types of knowledge serve to render absent entire worldviews and sectors of the population. Traven establishes a contrast between what his narrator terms "embodied philosophy" and the judgement that comes out of a classifying, authoritative knowledge. Importantly, his narrator is not really typical of a "Totenschiff" crew. Many of the crewmembers are on the "Totenschiff" because of structural expulsion and subjugation; Pippip, in contrast, is at least partially there because he refuses to accommodate to the hegemonic bourgeois models of civilization: a sedentary lifestyle, a patriarchal family, compliance with state authorities. He metaphorizes this as looking beyond the wall: "Ordinary people can never fall over the walls, because they never dare climb high enough to see what is beyond the walls.. ${ }^{20}$ Once he is dispossessed of his nationality, this personal life choice turns into an unforgiveable sin against the status quo; that is, he falls over the wall he tried to look beyond. When we first meet him, he is still called Gale, has a seaman's card, and works as a deckhand on a decently run ship. He then misses his ship and loses his identification papers because of a careless act of hedonistic pleasure hunting and the desire to assert his virility. Traven then makes the reader accompany Pippip's gradual transformation from a mobile labourer with identification papers 
and civil rights, first into an expulsed labourer with a fluid identity, and then into a wretched expulsed creature. One of Pippip's most defining character traits is his refusal to engage with notions of ownership or possession. Traven expresses this through Pippip's relationship to water and fluidity. Pippip is content and active only when he is either on water (on a ship) or by its shore (in a harbour or on a beach). He stagnates and feels weighed down by the good life or constrained by rules whenever he is in non-coastal regions. Because he cannot bear himself in this state of existence, he leaves these areas and moves on to the proximity of either the Mediterranean or the Atlantic Ocean. At that point, Gale defies the State and the five hegemonic logics; but thanks to his adaptability and inventiveness, and other people's solidarity and kindness, he is fairly happy in himself. Traven conveys this in a concise sequence of episodes situated hours before Pippip first sets eyes on the Yorikke. Pippip sits at the Barcelona harbour fishing, initially with the intention to eat the fish he catches but also because he enjoys fishing as "embodied philosophy." ${ }^{21}$ He catches three fish, all of which he talks to and all of which he releases into the sea. The first fish he lets go out of empathy, because the fish's wriggling when being scruffed by him, reminds him of himself wriggling when he is scruffed by a cop. The second fish he releases for the sake of justice with the comment: "I won't be introducing class differences now! I let the other one go, now I cannot sentence this one to death for his stupidity." The last fish he slips back into the water because it is too small to make up a full meal, and because he appreciates the beauty of the creature - and in the name of freedom:

For how long has this lovely life laboured on you, just to bring you up to such an insignificant size? Six years, possibly seven. And now I'm supposed to kill you with one blow and end your life? Off you go, enjoy the blue sea and your companions! Look at him sashaying away. You know what freedom is worth, little guy, don't you? Take joy in her, appreciate her and be happy. $^{22}$ 
When questioned by a passing customs officer on why he fishes if he does not keep the fish, he responds that he fishes so that in the end of the day he can give accounts of what he has done. The customs officer is satisfied with this tongue-in-cheek summary of futility and tells Pippip to keep going. Pippip then shares his true motives with the reader/listener: "Es ist doch nicht des Habens wegen, dass man lebt, sondern des Wünschens, des Wagens, des Spielens wegen, dass man lebt.”/ "Surely it is not for the sake of having that one lives, but for the sake of desiring, of daring, of playing that one lives." 23 The fluid Pippip who enters the "Totenschiff" can be thoughtless and careless, even opportunistic; he is unable to find himself in any activity or relationship that requires nurture, safekeeping, staying power, or sustained care; there is an element of self-absorbed cruelty in his playful indecision and open-endedness with the fish, for he could surely spare them the anguish of being caught if he only committed to not keeping any of them. But he does not desire possessions or status, nor does he wish to dominate other creatures or damage them for his benefit. He never treats the fish as a subordinate species, but as creatures in their own right; and when he touches fluidity, he does not grasp and consume the fish that embodies it, but lets go of it, sets it free. Of course, the State and “civilized society" cannot leave space for such light-hearted, mischievous, sustained mockery and defiance of everything they stand for; and Pippip ends up jumping off the harbour wall and into a trap facilitated by his own sense of superiority.

For, while Pippip develops an un-classifiable and de-classifying type of knowledge out of his interaction with the innocent fish, he deploys a study-based, authoritative type of knowledge when he gazes at abject objects or people. Immediately after the above sequence, Pippip first sets eyes on Yorikke and her crew - still from the vantage point of an honest sailor who has fallen into bad luck:

The whole thing [Yorikke] was a huge joke. Looking at it, one wouldn't believe that it could ever keep above the water. One would readily believe, though, that it might be an excellent means of transportation over the Sahara Desert. [...] 
Her shape was neither modern nor pre-Roman. To try to place her in any period of shipbuilding was futile. She did not fit in any age I could think of. In no marine-museum anywhere in the world had I ever seen a model like that one. [...]

I was interested in the colour of the hull. I couldn't make it out. It looked as if it had been snow-white when the ship was still in her baby-shoes. That, however, must have been some time before old man Abraham left Ur or the Chaldees with his wife Sarah. I could see that at least two hundred new layers of paint had been put on top of the original white. As a result there were as many different colours on her hull as are known to exist. Those layers of paint made her appear twice her true size. [...]

To call her a sane ship or a normal vessel would have been an insult to all the other ships that sailed the seven seas. Her appearance agreed perfectly with her mind, her soul, her spirit, and her behaviour. Only an insane ship could look like that. ${ }^{24}$

Pippip immediately identifies an affinity between the ship's and his own condition: the name of the ship's home port is illegible and the flag looks so that "it might have represented any flag of any country in the world." 25 Seduced by this affinity and driven by his desire to not only climb up the wall, but also find out what is on the other side of it, he accepts a job on this tatterdemalion vessel. His gaze on the tatterdemalion crew differs profoundly from his gaze on the ship, which drew on knowledge based on history and maritime technology:

One of them wore neither cap nor hat; no, he had wrapped around his head, turban-like, a rag from a woman's petticoat. Another [...] wore a high black silk hat. Figure that out, a sailor with a top hat aboard an outgoing freighter. [...] There was another guy there who had on full evening dress, and very elegant too. Since he was only half the size of the clothes he wore, and since the man with the top hat looked more like the former owner of the evening 
dress, I knew the whole story. [...] Others were clothed, or better, bedecked, with ragged pieces of sacks. One wore instead of a man's shirt a kind of woman's blouse which was probably missing somewhere from the upper room on a tavern in a North African port. ${ }^{26}$

His judgmental gaze on the crew is informed by assumptions regarding the dress and behaviour of honest sailors, and regarding the ideal male working class body, an ideal which, as Valerie Burton among others has pointed out, had undergone a shift in the $19^{\text {th }}$ century when "the ideal male body transformed from lean and wiry to bulky and physically powerful." 27 Superiority was established through a contrast with the Bodies of the "Others": "The image of the strong muscular white body took its meaning from its contrast to the primitive, savage, animal-like bodies of racial, ethnic and classed 'others." ${ }^{28}$ Both assumptions are contingent on Pippip's own status as an honest sailor - a status he holds on to in his self-awareness, even though he has already lost it in the awareness of others. His judgmental - as distinct to, critical - gaze makes him jump off the wall he is sitting on: he accepts a job on Yorikke and turns himself into the skipper's prey. Once the Yorikke has left the port, it turns out that the ship's officers have tricked Pippip into accepting a job with terrible conditions; no matter how much he wriggles as they metaphorically scruff him by the neck, they will not let go of him and set him free.

Once he has become prey, he develops a knowledge based on sensation rather than on external frameworks of reference. This is first indicated by the changing nature of his gaze. Initially, when looking at his shipmates, he expresses his conviction that he will not be able to turn his body into one of those "primitive, savage, animal-like bodies" he subjects to his exoticizing gaze, for example when he watches his friend Stanislav, who shows him how to squeeze his body down the tunnel that leads to the stokeroom:

I watched him throw his arms above his head to protect his face and neck against the steam 
sword. Then more agile and swift than a young snake, he twisted his body through this labyrinth of hissing steam-pipes and darts of shooting steam rays, so that, before I had caught my breath on seeing his elegant acrobatics, he was across to where the ladder went below. [...] When I saw Stanislav doing the snake-dance, I thought highly of his ability, and I felt that no one else could do it so elegantly. I learned soon that every member of the black gang could do the same. He had to. Because only the best snake-dancers survived the black gang. ${ }^{29}$

In German, Pippip uses a rich, colloquial and quirky lexical field to first illustrate his view on Stanislav's body, and then convey the transformation of his own body into one like his friend's. What is translated as "young snake" is a "Zitterschnecke" in German, literally a "trembling snail." The "snakedance" is a liberal translation of "Schlangenmensch," which designates a non-gendered "snake-humanbeing" which refers to hyperflexible circus artists, contortionists; thus, a type of person and not an activity, and one that the gaze cannot capture into a pose, but which the gaze can only follow as they move. Once Pippip himself descends into the stokehold, his perception adjusts to the hellish environment. His description of the bodies of the stokehold crew inside the boiler room conveys the existential status of life as flickering between the human and the non-human in sub-human conditions, for example when he watches the fireman's body in the flames and describes him in German as "Gestalt" (translated into English as "human shape"), a term which can only refer to living creatures but does not connote human subjectivity or gender.

Over the coming months Pippip's body, his modes of perception, understanding, and identification transform. Knowledge is now linked to sensation rather than perception or reflection, and time is no longer linear, but an impasse. Pippip gradually adjusts to malnourishment, lack of sleep and hygiene, and to physically destructive, even deadly work. He no longer looks at his shipmates or himself (there are no mirrors on any “Totenschiff”). His perception focuses on smell (mostly the 
stenches emanating from his environment), touch (always of a painful nature, such as violent impacts of heavy objects, burns, scorching, and grating), and on internalized circular overthinking (varying between self-limitation, incredulity, rebelliousness, and reinvention of himself). His sensations convey that his body is now like his shipmates': emaciated, covered with burns, cuts and bruises, his skin blackened by coal and grated and pigmented by the ash and sand the men use in the absence of soap, and wiry, strong, and flexible. His relationship to Yorikke becomes symbiotic, and his body is testament and testimony of their interaction:

Honest, baby, I love you. I have six black finger-nails, and four black and green-blue nails on my toes, which you, honey, gave me when necking you. Grate-bars have crushed some of my toes. And each finger-nail has its own painful story to tell. My chest, my back, my arms, my legs are covered with scars of burns and scorchings. Each scar, when it was being created, caused me pains which I shall surely never forget. But every outcry of pain was a love-cry for you, honey. You are no hypocrite. Your heart does not bleed tears when you do not feel heartaches deep and truly. You do not dance on the water if you do not feel like being jolly and kicking chasers in the pants. Your heart never lies. ${ }^{30}$

On land, Pippip is now the object of the gaze of the "civilized" population, just like the other crewmembers used to be the objects of his gaze: the owners of the bars and the police constantly observe them with suspicion and alarm, women pale and hide, men turn around and walk away, and children eye them with a mixture of terror and fascination. The port authorities, when they board the ship, do not look at all: they have a chat with the skipper, give him all his permits, ignore the crew, and walk away. Neither the "Totenschiff" nor its crew are invisible; they are forcibly rendered absent by different populations for different reasons. The port town populations interpret them as a threat because they defy classification; the fellow seafarers look at them with disgust or pity because according to the 
classification systems of organized labour the "Totenschiff" crews are their inferiors; and the authorities only take notice of the other person in authority, the skipper. None of them see the crew and, conversely, none of the onlookers see the "Totenschiff" as the mirror image of their own complacency, indifference and self-interestedness, of the greed of predatory capitalism and of "a State which desires to, and must, evolve to the limits of its own reason." 31

The late $20^{\text {th }}$ century predatory capitalism in Seaman replaces overwork and profiteering with passivity, apathy, and futility. The Urus is the product and perpetuator of a Jamesonian postmodernism in which only the image matters. The ship is the project of two social failures, Elías and Mark, who feign success by reinventing themselves and each other in the roles of the captain and first mate, though Elías' only maritime qualifications are a few years at maritime school before dropping out, and Mark's are none at all. Rather than making a financial profit by exploiting and subjugating potentially rebellious or insurgent sectors of the population, the skippers of the Urus exploit the vulnerable and drain them of their physical and mental energy so that they can reinvent themselves. Stagnation, inertia, neglect, abandonment, and attrition, rather than the hellish firepower of the boiler room, provide the conceptual space for the ship's and the crews' bodies and, in some cases, their minds. The crew are mostly very young men who have never left their country, let alone been to sea, with the exception of the elderly waiter Bernardo and the alcoholic cook. They are hired by agencies in Nicaragua and Honduras, and flown to the United States. They do not speak English, and the "officers" frighten them into avoiding any excursions on shore. Most of them display a naive trust in the officers, which prevents them from listening to Bernardo, who grasps their situation as soon as he sets eyes on the ship:

Three derrick-rigged King masts protruding over the long main deck. Urus painted high up on the prow against a dark smear covering up what must have been its previous name; Urus, Panama City on the stern. But there were no lights onboard; everything looked painted with shadows. The deckhouse, whitish, speckled with dark fashes, was back near 
the stern; two rows of black portholes visible beneath the bridge and wing; a smokestack. The ship's ladder was up. Water rustled heavily against ship and pier, slapped pilings. The heat still held itself over everything like someone at the very end of holding his breath.

Then Esteban heard Bernardo whispering in his ear that the ship was nothing but a broken eggshell, chavalo. ${ }^{32}$

Unlike Yorikke, who gypsies through eras and temporalities, the Urus remains stagnant. The ship's contours can be traced only at the peril of tearing one's skin on the jagged edges or falling into one of the holes; and only with difficulty can we apprehend these contours visually: the Urus is corroded by colourless rust and "painted with shadows," which are impossible to capture or apprehend, and which change shape continuously. In this one sentence "There were no lights onboard; everything looked painted with shadows" Goldman creates a flickering ambiance which is both impossible (there are no shadows without light) and real (Bernardo sees it with his own eyes). The verb "looked" - chosen over the grammatically more appropriate "seemed" - removes reflection and mediation and insists instead on the directness of sensory perception. The spatiality of the ship intersects with its temporality, marked by water rustling heavily against ship and pier, and slapping pilings, and intensified through Goldman's use of commas and semicolons, which transfer into writing the rhythm of the ship bobbing up and down in still waters. Goldman's use of the verb "to hold" - the heat still holding itself over everything like someone at the very end of holding his breath - conveys the stagnation of time, energy, and life: nothing is exempt from the hold of the heat, which, self-sufficient and self-possessed, holds itself and also has a hold over everything else.

While Bernardo is there, the Urus is constantly being cleaned and painted by the crew, which mirrors the waiter's reproductive labour, expressed in his incessant attempts at washing and mending the crews' rags, cleaning the kitchen and removing cockroaches from the rice that is the largest part of their diet. As time progresses, the exteriors of ship and crew dilapidate in even measure. The officers 
stop coming, and Bernardo is taken away after a terrible accident. ${ }^{33}$ Eventually the captain paints over the name of the ship and deletes the last traces of its official identity. Most of the crew resign themselves to this fate. When the Ship Visitor finds them, he tells himself (or us?) to do what the authorities never do when they board the Yorikke: "Look at them, the poor fucks. But look at them."

[They] will strike him, on first impression, as strangely incurious, or maybe just shy, or totally lost in benumbed stupors. Smoky smelling, black-smudged khaki blankets tugged around their shoulders for warmth over torn and stained clothing, and for all the boyishness of their faces, grimy and unshaven, with soft little beards. A few hard-eyed stares, others vacant, dazed. [...] Central Americans. Young. Practically boys! Just a bunch of filthy, fatestunned boys! $!^{34}$

The bodies of the crew are overpowered by a ship that never sails. In contrast to the savage exploitation of the workers on Yorikke, the Urus confines the crew's bodies to patterns of inactivity which result in mental and physical passivity. Rather than using their minds critically, they remain stunned by fate and relinquish critical reflection to monotonous games of domino, meaningless conversation and, in some cases, the damage of paint solvent fumes. The Ship Visitor's gaze on them is compassionate, wellintentioned, sympathetic, and unhelpful. He sees people who need to be rescued - and the flip side of officialised rescue is deportation. In this context, the crewmembers' identification in terms of their own nationalities as Honduran or Nicaraguan establishes a crucial difference to the stateless characters in Totenschiff: because they confess their nationalities to the Ship Visitor, the State can then deport them to their countries of origin. Only Esteban constructs his relationship towards the State not through the nation, but through his politically based experience of the Sandinista struggle and his critical analysis of the present moment. He is the only one not on board when the Ship Visitor first arrives. Subsequently, Esteban avoids the Ship Visitor and builds an alternative to deportation. 


\section{A "minute, imperceptible sign of complicity": The right to escape}

As Marcus Rediker points out, the alternative to deportation consists of the actualization of the "right to escape", ${ }^{35}$ and this is where the second challenge of both novels to their readers lies: to become accomplices of those who are willing to actualize this right. Such complicity requires what I will call, borrowing from Édouard Glissant's Poetics of Relation, an “imperceptible sign of complicity.” Glissant develops the term when he recounts his attempt at communicating with a young man who "had the opportunity to take refuge $[\ldots]$ in absence":

I'm not sure what he was called, because he no longer answered to any given name. One morning he started walking and began to pace up and down the shore. He refused to speak and no longer admitted the possibility of any language. [...] All the languages of the world had come to die here in the quiet, tortured rejection of what was there. [...] I made an attempt to communicate with this absence. [...] the second or third time around [...] he replied with a sign that was minute, at least to my eyes; for this gesture was perhaps the utmost he was capable of expressing: "I understand what you are attempting to undertake. You are trying to find out why I walk like this - not-here. I accept your trying. But look around and see if it's worth explaining. Are you, yourself, worth my explaining it to you? So, let's leave it at that. We have gone as far as we can together."36

From then on, Glissant and the young man recognize each other with that minute, imperceptible sign of complicity, the "barely lifted hand." 37 In the cases studied here, this minute imperceptible movement signals that someone on a "Totenschiff” has not submitted to becoming the Totenschiff's creature; or that someone in a port notices the Totenschiff for what it is and will not turn its crew over to the skipper, to the authorities, or to a hostile public. Without the shared recognition of these dispositions 
and insights, the right to escape cannot be actualized.

Rediker argues that the "right to escape" was a fundamental right of seafarers, though it was denied them by the port authorities and the officers. Thus, seafarers had to actualize it autonomously. Rediker points out that the escapee has in literature, historiography, and economic theory often been treated as "the individualist, over and against the collectivist who rose in insurrection." 38 This, he argues, is an ideologically informed misrepresentation: the escape is usually a collective act that involves a variety of people, skills, and knowledges. Based on his analysis of the autobiographies of $18^{\text {th }}$-century seafarers Edward Barlow and Henry Pitman, we can identify several elements that, as we will see, affect the $18^{\text {th }}$-century cases studied by Rediker as well as all the $20^{\text {th }}$-century fictional characters of Esteban and Pippip. All four potential escapees encounter two major challenges in attempting to actualize their right to escape. Firstly, they need to find the resolve to do so while they are still on the ship; and secondly, they have to find accomplices off the ship.

Barlow and Pippip - who fail to actualize their right to escape - were dispossessed of land and nationality respectively, and grew up in dire poverty. Their dispositions are marked by them being adventurous, intellectually curious, rebellious, and by their abhorrence of injustice, their rejection of hierarchies and authorities, and their desire for autonomy. Both have a high level of self-education: Barlow taught himself to write, read, and draw, and Pippip is conversant with History and well-read in the literary classics. Both preserve their life stories, and claim authorship and subjecthood by using the first person. Both state explicitly that they cannot actualize their right to escape because of wage dependency, and indicate implicitly that they do not actualize it because they do not have allies off the ship.

Pitman and Esteban - who do actualize their right to escape - have both participated in armed political struggles (the Monmouth Rebellion and the resistance against the Contra) that did not achieve their aims. Yet, Pitman and Esteban hold on to their values and principles throughout defeat and repression. They draw on skills and experiences from their previous struggles: quickly assessing 
situations and dealing with them creatively, resisting fear, and making alliances. Pitman also draws on knowledge of geography, navigation, carpentry, and medicine, and Esteban, on a strong work ethic. Both have learnt, from their previous exposure to hierarchical organisations, a critical approach towards authority. Importantly, both have someone who helps them, and someone to go to: Pitman returns to a loving family who had been pleading his cause while he was in captivity and banishment, and Esteban builds a romantic complicity with the strong-willed Mexican manicurist Joaquina, a friendship with her boss Gonzalo - a gay former-variété-dancer-turned-hairdresser Cuban émigré -, and a community of solidarity among the documented and undocumented Latino immigrants in Brooklyn.

What interests me here are the dispositions and actions that are so crucial to the building of complicity and to the actualization of the right to escape; and the dispositions and actions that get in the way. In Pippip's case, what gets in the way is how he deploys critique, as well as his male-centred approach to relationality and complicity. As for the former, once Pippip loses the grounds on which he classifies and judges other people - as we saw in his first encounter with the crew of the Yorikke -, he submits his critical and inquisitive spirit to Stanislav's “Totenschiff”-based reasoning:

"No way ever to get off [the Totenschiff] again, once on. If you really make it and have luck in skipping the can, they catch you within a day or two and take you straight to another death tub. What else can they do with you? They have to get you out somehow. Can't deport you. You haven’t got a country to be deported to."

"But, Lavski, how can they make me sign on? They cannot do that." "Yeah? Can't they? You should see how they can. The skipper, always in need of hands, even pays them a pound or two for bringing you in. He swears that he has signed you on by hand-shake in a tavern, and that he has given you two bobbies advance. A skipper, such a fine man, is always right; the sailor is always drunken and of course always wrong. You 
have never seen the skipper; neither has he seen you. But he needs you and claims you as a deserter. And don't you try the court. That's the curtains for you." 39

He never engages in an autonomous critical analysis of his situation, of the stories that Stanislav shares with him, or of the ways in which Stanislav tells these stories. If he did this, he would jeopardize the terms of their caring, affectionate, and co-dependent friendship. Instead, Pippip follows the example of the other members of the black gang and metaphorically hits his head against the kind of wall he formerly liked to climb. They rebel against the officers in sometimes highly effective ways: several times they chase terrified blood-streaming officers across the ship until they barricade themselves in their quarters. The black gang could probably even sail the ship, for they are all accomplished seafarers. Yet, they do not break down the door and take over the ship, because those crewmembers who are hierarchically located above them would not support a mutiny, let alone piracy. They protect their little privileges by colluding with the officers. The black gang, in turn, fear the unpredictable vindictiveness of their shipmates more than an oppressive exploitative system within which they know how to subsist. This constellation repeats itself time and time again, and the act of rebellion turns from the black gang setting and defending their own boundaries, into short-term self-assertion that effects no change.

Esteban isolates himself from all crewmembers except for Bernardo, with whom he has an affectionate but critical relationship. He treats them with courtesy; they consider him a weird recluse, and some mock him for not participating in their banter and for not laughing at their reactionary, misogynistic, sometimes homophobic and often self-defeating jokes. While they give themselves over to decay and turn the "Totenschiff" into their universe, Esteban uses silence and inaction to take a thorough look at painful and frightening experiences from his past. He learns from some of his experiences, takes nurturing elements from others, lets go of some, and adapts his knowledge and skills to his present situation. His unreceptiveness to the Sandinista high command's verbal and structural performances of power translates into unreceptiveness to Elías's and Mark's performances of power 
and virility, and to Bernardo's benevolent paternalism. His critical responsiveness to the political and literary training he received translates into him engaging with the wider implications of his situation and not accepting it as given. His respect for the militarily competent and ethically and politically coherent leadership style of a commander who eventually gets deposed, and his commitment to some Sandinista principles brings him to develop an analogous ethical coherence. In the completing stages of his internal process of reflection, he starts to disobey the officers and to confront his own fear of the port town populations. He secretly leaves the ship to look for a life beyond the derelict and decrepit landscapes he inhabits and, metaphorically, for a life which is not ruled by fears and ghosts. This is when he meets Joaquina and, through her, Gonzalo and the Hispanic community. With their support, he soon ruptures the symbiotic relationship between his own and the ship's body that Pippip celebrates in his own case. Esteban, after looking at himself in a mirror in Gonzalo's salon and finding that "he looks like one of those boys raised by wolves, ${ }^{40}$ spends his first dollars on a haircut.

The second crucial difference between Esteban's and Pippip's ability to escape lies in their approach to their accomplices. Both find an accomplice, and in both cases she is an independent working class woman who defies conventions of bourgeoise femininity. Pippip meets her in a café in Marseille just before he boards the Yorikke, when he is hungry and has no money for food. The waitress calls him out on this and, when he admits it, passes a plate among the forthcoming and generous customers, asking for donations for a sailor in bad luck. She then offers Pippip a place to stay for the night. Pippip, shy and intimidated (he calls it "gentlemanly" in English and "Kavaliersein" in German), offers to sleep on the floor. She laughs at him and explains that the invitation is about him sleeping with her in her bed. The next morning she asks him to make sure that her landlady does not see him leave, because she would raise the rent thinking that the waitress "made some money on the side." She addresses the social prejudices against women who are agents of their desire without herself passing judgement on sex workers. This indicates how these prejudices jeopardize her economic autonomy, and makes clear that their night together was not a transaction. She tells him that he may come back 
any time, and that there will be food and a bed for him. In his telling of this episode, Pippip tries to bury her independence under assertions of his virility (that is, him satisfying her sexually), and dismisses her kindness and intelligence in the face of adverse circumstances by emphasizing his devious cleverness, upon which he bases his assumption that a woman who works in a port town café will not spot the difference between a German and an American accent and will therefore believe his fibs about his nationality. Then, he forgets her. What is worse, by the end of his time on the Yorikke, Pippip has reinvented himself as a "whoring, drinking sailor" in the company of a misogynistic allmale crew. ${ }^{41}$ Some of his remarks suggest that he can no longer conceive of his scorched and battered body as a site of mutual pleasure, and pleasure (of any kind) is how Pippip opens up to potentially positive experiences. In all his fantasizing about escapes, even when he is tied to a plank and is floating in the ocean, he does not even consider the option of going back to the waitress and exploring the possibility of an alliance with a woman who does not articulate her desires or dispositions in terms of neediness and submission. Instead, he sells stories to a readership that only listens when addressed by a male voice in the register of its own masculine authority, is socially ranked above him, and demands his submissiveness.

Esteban, in contrast, consistently returns to his accomplice Joaquina until he stays with her for good. They first meet when Joaquina mistakes Esteban for a tramp who pisses in the doorway of the salon where she works. He protests against her mistake and she hears him out. Like the waitress, Joaquina works in a feminized profession in the service industry, is hard-working, economically independent, smart, determined, from a humble background, outspoken (initially Esteban devalues this character trait as "bocona," or "mouthy"), the agent of her desire, and generous without being patronizing. Their complicity is built by both with an equal amount of effort. Joaquina leaves her lawyer boyfriend from Mexico City. Esteban leaves the male-dominated space of the ship for the stereotypically gay and feminine salon. After some advice given by Bernardo, Esteban revises his attitude towards women: when he complains about Joaquina being "bossy" and "aggressive" (that is, 
speaking her mind and doing what she wants), Bernardo replies: "Chavalo, bossy, difficult women are the greatest thing on earth! ... I tell you, they only do it out of love, and they never let you fall asleep at the wheel. And after, docile women seem tepid forever. Why should it bother you that she has a lover? It's good that she's not a prude." "42 After this, Esteban swaps his machismo for curiosity for, and enjoyment of, Joaquina's femininity and a reinvention of his own masculinity. He also lets go of his grief for Marta, his dead lover from Nicaragua, a brave, caring, soft-spoken, mild-mannered, highly educated young woman from a class background that combined inherited wealth with educated professionalism. He finds a place for the memory of her, symbolized by a treasured Micky Mouse watch she gave him. He finally adjusts it to New York time and ends the impasse of his grief. In contradistinction to the privileged Henry Pitman who gradually left behind his fellow escapees, Esteban extends his escape to his shipmates: when the Ship Visitor advises them of their imminent deportation, Esteban calls on previously made offers of food and a place to sleep from the Hispanic community so that his shipmates have somewhere to go. By the end of the novel, he lives in his present moment as a respected member of the community and in his partnership with Joaquina, where sex and elements of domesticity bind them together in a complicitous imagining of and experimenting with intimate relationality.

It is important to note a difference in the initial signs of complicity and in the circumstances of the first encounters. The waitress gets Pippip (then Gale) the money for food in a way that establishes a relationship between him and the collective of the café's patrons; rather than, for example, her asking favours of the cook. However, when she does so she affirms, and probably shares, his deluded selfimage of a sailor in bad luck. Neither of them acknowledges their status as dispossessed and, consequently, they place their interaction on the level of chance rather than any type of durable complicity. This is compounded by Pippip being a sea-bound vagabond, and as a result they have no consistency within which they could grow relationality - though she tacitly opens up the possibility of at least experimenting with it when she tells Pippip that he may come back. As things stand, they 
dedicate that one night to what is crucial to both their personalities, pleasure. Joaquina, in contrast, argues with Esteban, then hands him a mop, gets him to work for his money, contains the incipient relationship within a small group of intimate and trusted friends who do not constrict people or relationships, and the two only sleep together after a significant amount of time has passed. In other words, Esteban and Joaquina appropriate the inertia of the Urus for their own purposes.

These two different approaches to the right to escape suggest that Stanislav's analysis of the impossibility of escape from the "Totenschiff" is more perceptive and more blinkered than he and Pippip notice at the time. Stanislav is right in that one cannot escape from the "Totenschiff" by running away from it; and this is so because the only potential accomplices and obstacles he identifies are men in position of power, who dominate over and oppress other men. To climb across that wall, the men would have to give up on male supremacy, the only power source that is left to them on "Totenschiff" terms. This is inconceivable to them all - except to the most wretched of a group of damnés.

\section{Conclusion}

Traven ends Totenschiff with Pippip trapped in the impasse of storytelling, literally and metaphorically dogpaddling as he peddles for a pittance the story of himself floating in the ocean, having lost his only friend to the attraction of the "Totenschiff," tied to a plank after latching on to his patriarchal masculinity. He stylizes himself into the literary archetype of all the men who defy reason and convention to actualize their desire for an existence outside of sedentary life - only to drift into the $21^{\text {st }}$ century tied to a piece of wreckage, repeating ad nauseam their heart-breaking, gut-wrenching, wasteful story of condemnation, oppression, costly futile rebellion, and death. Goldman ends Seaman by entrusting the crew of the Urus to the care of open-minded people who act in a spirit of solidarity, not rescue; that is, documented and undocumented immigrants, not the "civilized" populations who look across the wall only out of self-interested curiosity, or to stave off a possible spill-over of the dispossessed and the expulsed, of misery, or of a plenitude that would question the supremacy of the 
existent. The Empress sinks, the Urus crashes and gets towed, Stanislav and the crew of the Empress drown, Bernardo dies and is buried in an anonymous grave, Esteban and some of the crew walk off into the opacity of undocumented life, and the remaining crew members are deported home. All the inconvenient bodies are rendered absent, removed from the view of the "civilized" populations of the port areas, the authorities, and socially engaged readers - be it for their protection, or to perpetuate the status quo of predatory capitalism. Yet, Yorikke and her crew still sail the Seven Seas, and the Ship Visitor tells us with complete lucidity that even though the Urus has been taken away, there will be other ships like her. On the "Hidden Atlantic", the impasse of predatory capitalism thus extends from the $20^{\text {th }}$ into the $21^{\text {st }}$ century.

Both authors use fiction to convey facts and experiences of those who populate the "Hidden Atlantic" while protecting the opacity that protects them. In so doing, they invite social intelligibility and literacy for the many shades of the "hidden." Moreover, they open up space for a shared exploration of that crucial boundary we have to observe when we want to call out the systemic production of absences without handing over those who are rendered absent. As human beings, we exercise such judgement and actualize it in our social and political lives. As critical thinkers within an academic context, we have a responsibility to broaden the horizons of social and political intelligibility, to climb across that wall and to make our contribution to its removal - but that must not mean that we collapse all protective and containing boundaries. For, we work for an institution that joins the interests of corporations and the State and that invites, compels, or pressures us to carry out work that serves those interests. Moreover, we mostly move in the social space inhabited by the equivalent of the "civilized" port town populations who broadly identify their interests with those of corporations and the State, or at the very least acquiesce to predatory capitalism. In these circumstances, we turn the expulsed into the predators' next meal if we pull them into the celebratory, inquisitive, and invasive limelight shone on our outputs, while we are offered payback in the currencies of recognition, prestige, or (apparent) securities. 
Both authors give their readers good ideas on how to become allies of the expulsed. For that purpose, we have to become conversant in the minute, imperceptible, clandestine sign of complicity. We have to tune into those unclassifiable and de-classifying modes of understanding and responding, so that we can find our place and our role in the collective effort that is the right to escape. This, of course, is no longer an academic matter. But it can benefit greatly from the knowledges produced in the interdisciplinary meeting between literature, theory and history, which brings together complicity with opacity, and the lucid exposure of what has been hidden, and which can articulate the denunciation of the epistemologies, structures, policies, acquiescences, and the systemic and personal complicities that turn some humans into other humans' prey.

1 Traven, Das Totenschiff, pages in German original and in English translation.

2 Tabili, “A Maritime Race,” 177.

3 For the sake of conciseness, I will stick with the German term "Totenschiff", which has different connotations than the English "Death Ship." "Totenschiff" focuses on the people (die Toten - the dead), rather than the concept of death (Tod). The German term emphasizes that for the Totenschiff crews, social and physical death occur at different points in time.

4 Orlando Patterson's concept of "social death" would have provided an equally insightful - if different - conceptual starting point for a comparative of these two novels in the context of the "Hidden Atlantic." I chose Sassen's concept of the "expulsed" to emphasize the continuation of the problematics discussed here into the $21^{\text {st }}$ century, which is made more explicit with the use of a contemporary concept. Moreover, the dynamism inherent in "expulsion" highlights that some sectors of the population - bureaucrats and port town populations, for example - are actively involved in, and acquiesce to, the expulsion of others. Finally, my analysis emphasizes human agency (or lack thereof) over ontology, and it seeks to be alive to the characters' aliveness during 
experiences and situations characterized by death; the conceptual space that "expulsion" leaves to that aliveness is therefore helpful to the analysis presented here. Nevertheless, a comparative analysis through "social death", possibly integrating Achille Mbembe's "necropolitics", would make for an insightful comparative analysis of both novels. They are examples of intrusive (Totenschiff) and extrusive (Seaman) wage slavery; and in both cases Patterson's analysis of rituals and symbols is echoed in the signatures, name changes, specific clothing, and physical markings such as burns and artificial changes in skin pigmentation which mark the enslavement of both crews. One could even argue that Traven almost replies to Patterson's remark that European scholars have ignored or neglected the continuation of slavery in Europe after the Middle Ages (Patterson, Slavery and Social Death , 44-45); Traven suggests that those Europeans who become scholars are of a sector of society whose deluded self-image does not permit the exposure of the narrative of European modernity and enlightenment as fundamentally flawed and untrue. Finally, a conceptual comparison between Sassen's "expulsions" and Patterson's "social death" would be a worthwhile theoretical and methodological project that could then contribute to our understanding of the dimensions of different forms of slavery, forced labour, and impressment.

5 Gulddall, "Passport Plots," 299.

6 See Zeuske 2012 and 2016. Zeuske focuses on the Atlantic. Though Traven's Totenschiff is at least partially set in the Mediterranean, there is a sense throughout the novel that the ships transit easily between the Mediterranean and the Atlantic, and the conceptual dimension of the hidden elements of seafaring holds in both cases.

7 Lauren Berlant has theorized the "impasse" with reference to more contemporary literary forms as "a space of time lived without a narrative genre. Adaptation to it usually involves a gesture or undramatic action that points to and revises an unresolved situation. One takes a pass to avoid something or to get somewhere: it's a formal figure of transit. But the impasse is a cul-de-sac. [...] 
An impasse is a holding station that doesn't hold securely but opens out into anxiety, that dogpaddling around a space whose contours remain obscure. An impasse is decompositional - in the unbound temporality of the stretch of time, it marks a delay that demands activity." (Berlant, Cruel Optimism, 199)

8 A "Leichenschiff" (literally a "corpse-ship") is destined to sink and is therefore a physical death sentence for the crew. The Empress is unprofitable in terms of labour and commerce because of a manufacturing defect, and will therefore only make a profit for the owners if it sinks and the insurance pays up. The “Leichenschiff” recruits its crewmembers from the "Totenschiff” because only they can be left to die with impunity.

9 It is now widely accepted that Traven is identical with German Anarchist writer and actor Ret Marut. He played a significant role in the radical "Räterepublic" declared in Munich in 1919, and narrowly escaped summary execution in the same year during the brutal repression of this political alternative. He drifted across Europe, was arrested in London for several months under a different name, and disappeared off the authorities' radar in 1924. Traven himself had always denied that he was Marut, but his widow Rosa Elena Luján confirmed it after his death. To this day the "true" identity of Ret Marut (also a pseudonym) is still surrounded by controversy. See Guthke 1987 or, for a brief and more recent summary, Goldwasser 2001.

10 Valerie Burton points out that the stokehold crew was a product of the age of steam, and that they were considered "a whole new class of workers $[\ldots]$ Their work in the stokehold was only grudgingly accepted as seafaring by deck seamen [...]” (Burton, “A Seafaring Historian’s Commentary," 92). Pippip, who used to work as a deckhand, is initially unwilling to work in the stokeroom because he sees this as a downgrading of his status and rightly fears that it will remove his pleasure in seafaring.

11 See Tabili 1996 and Burton 2007 for an analysis of class and race on board of merchant ships until 
roughly the 1920 s, especially with regards to the racialization of the work on board and, in the case of Tabili's argument, specifically the work of the stokehold crew: they show how the most dangerous, worst-paid work was increasingly often carried out by Black and Asian men. Traven registers this process in one of the shifts in everyday life between the vagabond, working-class Yorikke and the pretentious majestic Empress. On the Yorikke, race does not play into the social ranking among the crewmembers, though race is sometimes noted and, for white crewmembers, ignored; indeed, Pippip's claim that he is half Egyptian and half Abessynian is never questioned. On the Empress, work is racialized and crewmembers are segregated: Pippip and Stanislav now work in a slightly higher position in the stokehold crew, as heaters; the coal-drags are African-Americans. White crewmembers ignore them, except Pippip and Stanislav who generally keep to themselves but build a courteous and mutually supportive, if distant and unequal, relationship with the AfricanAmerican coal-drags.

12 Das Totenschiff was first published by Büchergilde Gutenberg, a German association founded in 1924 by print workers to facilitate access to books to the working classes within a solidary and autonomous structure. Thus, the implied readership are organized, engaged, intellectually curious, organized German workers, many of whom would have lived through repression during the Kaiserreich, the betrayal of Internationalism by the Social Democrats when they endorsed WWI, WWI itself, the Revolution, the clashes between the organized left-wing population and the monarchist and proto-fascist Freikorps, and inflation - and who were part of the embourgeoisement of the working class. The protagonists of Totenschiff are these workers" "Other": the lowest of the lowest, easily maligned and marginalized as Lumpenproletariat. Pippip as their spokesperson not only exposes the deceitful and exploitative maritime bourgeoisie and the complicity of the State and "civilized" society on land; he also articulates a scathing critique of the self-interested politics of organized labour, and of their disdainful attitudes towards those who were below them in the class 
system.

13 His other works include two novels (The Long Night of White Chickens and The Divine Husband), testimony (Say Her Name), and non-fiction (The Art of Political Murder).

14 Santos, The Rise, 15. I quote from Santos's rendition of this analysis in the English-language The Rise of the Global Left. The approach Santos outlines here is, however, taken from his Conocer desde el Sur, a philosophical analysis and critique of the dominant epistemology.

15 Santos, The Rise, 15-16.

16 Linebaugh and Rediker, The Many-Headed Hydra, 20.

17 Ibid., 28.

18 Maldonado-Torres, Against War, 218.

${ }^{19}$ Maldonado-Torres, "Coloniality of Being," 258.

${ }^{20}$ Traven, The Death Ship, 249-250.

${ }^{21}$ This passage was left out of the Picador translation which I otherwise quote in this article. All translations of quotes from pages 109 and 110 are my own. All other translations are taken from the Picador edition.

22 Ibid., 110.

23 Ibid., 109.

24 Traven, The Death Ship, 89.

25 Ibid., 89.

26 Ibid., 94-95.

27 Burton, “A Seafaring Historian's Commentary,” 39. Baron, "Masculinity, the Embodied Male Worker, and the Historian's Gaze," 149.

29 Traven, The Death Ship, 148.

30 Ibid., 263-264. 
31 In the case of Totenschiff, the statelessness of the crew is a crucial factor in the process analysed in this passage; however, this is not the case for Seaman. Because this is a comparative paper, I will not go into this in greater detail here but refer readers to Gulddall 2013 and 2015, where the role of statelessness and passports is discussed with reference to Das Totenschiff in great analytical richness.

32 Goldman, The Ordinary Seaman, 20.

33 Bernardo, the character who performs the reproductive labour on board, has to cook over an open fire because of the faulty cooking equipment. When he accidentally pours oil over his leg, Elías, who pretends to be a licensed herbalist, treats him on board and refuses to take him to a hospital. When his condition deteriorates dramatically, Mark, the "first mate," anonymously takes him to a hospital, where Bernardo dies. This accident has a point of comparison in Totenschiff. Stanislav tells the story of the coal-drag Paul, who also dies a horrible death after suffering burns when repairing faulty equipment in the boiler room. Coal dragging is also a kind of reproductive labour. Neither of the two deaths is registered: Paul's body gets tipped overboard with a lump of coal tied to him, and Bernardo is buried anonymously. In Bernardo's case, the Ship Visitor eventually uncovers his fate. Since the Ship Visitors who make it onto the Yorikke only speak to the skipper, they never discover anything and the crew of the Totenschiff lives without such external assistance.

34 Goldman, The Ordinary Seaman, 130.

35 Rediker, TITLE, page range

36 Glissant, Poetics of Relation, 122-123.

37 Glissant, Poetics of Relation, 123.

38 Rediker, Outlaws of the Atlantic, 62.

39 Traven, The Death Ship, 68.

40 Goldman, The Ordinary Seaman, 213. 
${ }^{41}$ For the stereotype of the "whoring, drinking sailor" and its shifts during the $19^{\text {th }}$ and early $20^{\text {th }}$ century, see Burton 1999.

42 Goldman, The Ordinary Seaman, 27.

\section{Disclosure statement}

No potential conflict of interest was reported by the author.

\section{References}

Baron, Ava. "Masculinity, the Embodied Male Worker, and the Historian's Gaze." International Labor and Working-Class History 69 (Spring 2006): 143-160.

Berlant, Lauren. Cruel Optimism. Durham, NC: Duke University Press, 2011.

Büchergilde Gutenberg, “Geschichte der Büchergilde.” Accessed 10 October 2017 https://www.buechergilde.de/geschichte.html.

Burton, Valerie. “"Whoring, Drinking Sailors': Reflections on Masculinity from the Labour History of Nineteenth-century British Shipping.” In Working out Gender: Perspectives from Labour History, edited by Margaret Walsh, 84-101. Aldershot: Ashgate, 1999.

Burton, Valerie. “A Seafaring Historian's Commentary on 'The Body' as a Useful Category for Working-Class History." Labor: Studies in Working-Class History of the Americas 4, no. 2 (2007): 55-59.

Glissant, Édouard. Poetics of Relation. Ann Arbor: University of Michigan Press, 1997.

Goldman, Francisco. The Ordinary Seaman. New York: Grove Press, 1997.

Goldwasser, Jasper. "Ret Marut: The Early B. Traven.” The Germanic Review 68, no. 3 (1993): 133142. http://dx.doi.org/10.1080/00168890.1993.9934225. 
Gulddal, Jasper. 'Passport Plots: B. Traven's Das Totenschiff and the Chronotope of Movement Control." German Life and Letters 66, no. 3 (2013): 292-307.

Gulddal, Jasper. "The Novel and the Passport: Towards a Literary History of Movement Control." Comparative Literature 67, no. 2 (2015): 131-144.

Guthke, Karl. B. Traven: Biographie eines Rätsels. Frankfurt/Main: Büchergilde Gutenberg, 1987.

Linebaugh, Peter, and Marcus Rediker. The Many-Headed Hydra. London: Verso, 2000.

Maldonado-Torres, Nelson. "On the Coloniality of Being: Contributions to the Development of a Concept.” Cultural Studies 21, no. 2-3 (2007): 240-270.

Maldonado-Torres, Nelson. Against War: Views from the Underside of Modernity. Durham, NC: Duke University Press, 2008.

Patterson, Orlando. Slavery and Social Death: A comparative Study. Cambridge, MA: Harvard University Press, 1982.

Rediker, Marcus. Outlaws of the Atlantic: Sailors, Pirates and Motley Crews in the Age of Sail. London: Verso, 2014.

Santos, Boaventura de Sousa. The Rise of the Global Left: The World Social Forum and Beyond. London: Zed Books, 2006.

Sassen, Saskia. Expulsions: Brutality and Complexity in the Social Economy. New York: Belknap Press, 2014.

Tabili, Laura. “'A Maritime Race': Masculinity and the Racial Division of Labor in British Merchant Ships, 1900-1939.” In Iron Men, Wooden Women: Gender and Seafaring in the Atlantic World, 1700-1920, edited by Margaret S. Creighton and Lisa Norling, 170-188. Baltimore, MD: Johns Hopkins University Press, 1996.

Traven, B. Das Totenschiff. [1926]. Reprint. Frankfurt: Büchergilde Gutenberg, 1987.

Traven, B. [1940]. Reprint. The Death Ship: The Story of an American Sailor. London: Picador, 1988. 
Zeuske, Michael, "Historiography and Research Problems of Slavery and the Slave Trade in a GlobalHistorical Perspective.” International Review of Social History 57, no. 1 (April 2012): 87-111.

Zeuske, Michael. "Cosmopolitas del Atlántico esclavista: los "africanos" Daniel Botefeur y su esclavo de confianza Robin Botefeur en Cuba." Almanack Guarulhos, 12 (2016): 129-155. 